\title{
Dinamika Hukum Keluarga Islam di Kuwait dalam Bidang Perwakafan dan Wasiyyat al-Wäjibah
}

\author{
Haling Nasiki \\ IAIN Sultan Amai Gorontalo \\ Email: halingnasiki3@gmail.com
}

\begin{abstract}
The development of family law in an area follows the development of time, space, circumstances, intentions and customs in the area as Ibn Qayyim al-Jauziyah's theory. This article discusses the dynamics of family law in Kuwait related to waqf (charitable endowment) and wasiyyat al-wajibah (special wills). This research is a qualitative descriptive study with the Islamic legal approach method. The results showed that the dynamics of family law in Kuwait developed over time. In the field of representation in Kuwait, people apply two forms of waqf, namely waqf ahli (family) and waqf khairi (the interest for people) This provision adapted the system of representation in Egypt and Lebanon. This representation was stipulated by the Endowment Act of 1951. While in the field of wasiyyat al-wajjibah in Kuwait derived Egyptian legislation and used the opinions of Imam Maliki, Hanbali and Shafi'i, Wasiyyat al-Wajibah this is regulated in Law Number 5 Year 1977.
\end{abstract}

Keywords: Family of Law, Waqf, Wașiyyat al-Wajibah, Kuwait

\section{The Dynamics of Islamic Family Law in Kuwait in Field Waqf and Wașiyyat al-Wäjibah}

\begin{abstract}
Abstrak: Perkembangan hukum keluarga dalam sebuah daerah mengikuti perkembangan zaman, ruang, keadaan, niat dan adat pada daerah tersebut sebagaimana teori Ibn Qayyim al-Jauziyah. Artikel ini mendiskusikan tentang dinamika hukum keluarga di Kuwait terkait permasalahan wakaf dan wașiyyat al-wäjibah. Penelitian ini adalah penelitian deskriptif kualitatif dengan menggunakan metode pendekatan hukum Islam. Hasil penelitian menunjukkan bahwa dinamika hukum keluarga di Kuwait berkembang seiring dengan perjalanan waktu. Pada bidang perwakafan di Kuwait, masyarakat menerapkan dua bentuk wakaf, yaitu waqf ahli dan waqf khairi. Ketentuan ini menyadur sistem perwakafan di Mesir dan Libanon. Perwakafan ini diatue dengan Undang-Undang Wakaf Tahun 1951. Sedangkan pada bidang wașiyyat al-wäjibah di Kuwait menderivasi perundang-undangan Mesir dan menggunakan pendapat dari Imam Maliki, Hanbali dan Syafi'i, Wașiyyat al-Wäjibah ini diatur dalam sebuah UndangUndang Nomor 5 Tahun 1977.
\end{abstract}

Kata Kunci: Hukum Keluarga, Wakaf, Wașiyyat al-Wājibah, Kuwait 


\section{Dinamika Hukum Keluarga Islam di Kuwait dalam Bidang}

Perwakafan dan Wașiyyat al-Wäjibah

\section{A. Pendahuluan}

Alquran sebagai sumber utama hukum Islam memuat petunjuk tentang hukum keluarga, baik perkawinan, perceraian, hak waris, wasiat dan sebagainya sebanyak 70 ayat. ${ }^{1}$ Hal ini menunjukkan bahwa keberadaan hukum keluarga telah diatur dalam syariat Islam. Hukum keluarga dalam literatur fikih biasa dikenal dengan sebutan alạ̣wāl al-syakhṣiyyah. Aḥwāl adalah jamak (plural) dari kata tunggal (singular) al-ḥāl, artinya hal, urusan atau keadaan. Sedangkan al-syakhṣiyyah berasal dari kata alsyakhṣu - jamaknya asykhaș atau syukhuṣ - yang berarti orang atau manusia (al-insan). Al-syakhșiyyah berarti kepribadian atau identitas diri pribadi (jati diri). ${ }^{2}$ Hal-hal pribadi yang dimaksud adalah masalah-masalah di mana pribadi menjadi topiknya atau undang-undang yang mengendalikan masalah-masalah pribadi. ${ }^{3}$

Olehnya itu hukum keluarga bisa diartikan sebagai hukum yang mengatur hubungan internal anggota keluarga dalam satu keluarga (rumah tangga) yang berkenaan dengan masalah-masalah tertentu (pribadi), seperti pernikahan, keturunan (nasab), biaya hidup (nafaqah), pemeliharaan anak (hadanah), perwalian, kewarisan dan wasiat. Apabila dikaitkan dengan Islam adalah hukum keluarga Islam yang mengatur hubungan internal sebuah keluarga muslim.

Hukum keluarga Islam selama berabad-abad diakui sebagai landasan utama bagi pembentukan masyarakat Islam. Selain itu, kajian terhadap hukum keluarga Islam tetap penting dan terus berkembang juga karena dari persoalan-persoalan inilah selalu muncul perdebatan antara kekuatan konservatif dengan kekuatan-kekuatan progresif di dunia Islam. ${ }^{4}$ Hukum keluarga dalam implementasinya dalam kehidupan masih membutuhkan pengembangan selaras akibat adanya respon terhadap tuntutan perubahan yang terjadi di tengah masyarakat. Hal ini sesuai dengan pendapat Ibnu

\footnotetext{
${ }^{1}$ Abdul Wahhab Khallaf, Ilmu Ușul al-Fiqh (Bairut: Dār al-Fikr, t.th.), 34-35.

${ }^{2}$ Muhammad Rawas Qal'ahji, et al., Mu'jam Lugah al-Fuqahā' 'Arabi - Inklizi - Afransi (Bairut: Lubnan, 1416 H/1996 M.), 230. Lihat pula Ahmad Warson Munawir, Al-Munawwir Kamus Arab Indonesia (Yogyakarta: Pondok Pesantren al-Munawwir, t.th.), 49-750.

${ }^{3}$ Rifyal Ka'bah, "Beberapa Permasalahan dalam Al-Ahwal Asy-Syakhsyiah (Hukum Keluarga) Mesir, Makalah (Jakarta: Departemen Agama RI., 19 September 2002), 2.

${ }^{4}$ J. N. D. Anderson, Islamic Law in the Modern World, terj. Machnun Husain, Hukum Islam di Dunia Islam (Yogyakarta: Tiara Wacana, 1994), 46.
} 
Qغنير الفتوى و إختلافها بحسب تغير الأزمنة والأمكنة و الأحوال و النيات Qayyum al-Jauziyah bahwa perubahan ide-ide atau pemikiran hukum dan perbedaannya sesuai dengan perubahan zaman, ruang, keadaan, niat dan adat). ${ }^{5}$ Olehnya itu, eksistensi hukum keluarga sangatlah penting dalam sebuah negara.

Muhammad Amin Summa menjelaskan pemberlakuan hukum keluarga dibendakan menjadi tiga hal, yaitu Pertama, hukum keluarga dilakukan oleh negara secara tradisional, memberlakukan fikih mazhab dan tidak dikodifikasi dalam bentuk perundang-undangan, misalnya negara Saudi Arabia, Qatar, Yaman, Bahrain, Kuwait dan sebagainya; Kedua, hukum keluarga diberlakukan oleh negara dengan telah digantikankan dengan undang-undang atau hukum modern yang berlaku untuk seluruh penduduk, misalnya negara Turki dan Albania; Ketiga, negara yang telah melakukan pembaharuan dalam hukum keluarga Islam, misalnya negara Mesir, Sudan, Jordan, Syiria, Tunisia, Maroko, Algeria, Irak, Iran dan Pakistan. ${ }^{6}$

Permasalahan hukum keluarga misalnya dari segi perwakafan. Perwakafan merupakan salah satu warisan Islam yang memiliki peran aktif dalam menumbuhkembangkan kesejahteraan umat. ${ }^{7}$ Konsep pengelolaan wakaf telah dilaksanakan oleh negara-negara muslim di dunia, misalanya negara Mesir Kuno, dinasti-dinasti Islam seperti Saljuk dan Turki. Di negara Mesir kuno penerapannya dengan konsep misalnya para raja mempersembahkan tanah atau barang yang mereka miliki untuk dijadikan sebagai tempat menyembah dewa-dewa mereka, dan juga digunakan untuk mengumpulkan sumbangan berupa uang yang kemudian deserahkan untuk para pendeta. Juga terdapat wakaf keluarga dengan konsep, anak tertualah yang berhak dan atau memiliki wewnang untuk mengatur dan mengelola harta wakaf, dan tidak diperbolehkan memperjualbelikan harta tersebut. ${ }^{8}$

${ }^{5}$ Ibnu Qayyum al-Jauziyah, I'lam al-Muwaffiqīn al-Rab al-'Alamīn, juz 3 (Beirut: Dār al-Fikr, t.th.), 14 .

${ }^{6}$ Muhammad Amin Summa, Hukum Keluarga Islam di Dunia Muslim (Jakarta: PT Raja Grafindo Persada, 2005), 162-165.

${ }^{7}$ Ahmad Suwaidi, "Wakaf dan Penerapannya di Negara Muslim," Jurnal Ekonomi dan Hukum Islam, Vol. 1, No.2, 2011; 14.

${ }^{8}$ Muhammad Abid al-Kabisi, Hukum Wakaf(Jakarta: RajaGrafindo Persada, 2002), 17-19. 
Wakaf pada masa dinasti Islam memiliki peran signifikan dalam pembangunan negara, misalnya masa Dinasti Saljuk, harta wakaf dimanfaatkan untuk membangun tempat pemberhentian sementara kafilah dagang yang melewati jalur perdagangan, para pedagang diperkenankan untuk beristirahat selama tiga hari tanpa bayaran, dan memperoleh makanan gratis pula. ${ }^{9}$ Wakaf pada masa dinasti Ustmani berkuasa dikenal dengan istilah vakviye yang berarti pelayanan publik. ${ }^{10}$ Di sini wakaf telah memiliki peran dalam membiayai pelayanan publik dan pembangunan bangunan-bangunan seni budaya. Konsep wakaf dilakukan dengan cara pemilik tanah memberikan Hak bagi seseorang yang ingin memanfaatkan tanah dan kesepakatan di awal bahwa si pengelola dapat mewariskan tanah yang dikelolanya kepada keturunannya. Luas tanah wakaf pada tahun 1923 adalah 2/3 yang merupakan tanah subur. ${ }^{11}$

Di negara Irak (Kuwait Baghdad) pada masa dinasti Abbasiyyah, wakaf dikelola oleh seorang qodhi yang selalu memonitor wakaf harta bergerak yang ditampung dalam Baitul Mal. Wakaf tidak hanya diperuntukkan bagi fakir miskin, pada masa ini wakaf memiliki sebuah inovasi dalam pembagian harta wakaf, sehingga harta wakaf juga diperuntukkan untuk tempat-tempat ibadah, pengungsian, perpustakaan, sarana pendidikan, beasiswa bagi para pelajar, gaji bagi para guru dan orang-orang yang memiliki kaitannya dengannya. ${ }^{12}$

Permasalahan lainnya adalah wașiyyat al-wājibah. Misalnya di Mesir, Undangundang yang mengatur tentang ketentuan wașiyyat al-wājibah adalah Qânûn No. 71 Tahun 1946. Wașiyyat al-wājibah yang termuat dalam undang-undang tersebut berasal dari salah satu hukum agama yang bersifat taklîfî yakni wajib. Olehnya undang-undang memformulasikan dalam bentuk wasiat yang diwajibkan dan dibebankan kepada

${ }^{9}$ P.M. Holt, Ann K. S. Lambton and Bernard Lewis, The Cambridge History of Islam, Vol IA (Cambridge: Cambridge University Press, 2005), Hlm. 259.

${ }^{10}$ Tuti A. Najib dan Ridwan al Makassary, Wakaf, Tuhan dan Agenda Kemanusian (Jakarta: CSRC, 2006), 50.

${ }^{11}$ Ibid, 50.

${ }^{12}$ Mannan, Sertifikat Wakaf Tunai: Sebuah Inovasi Keuangan Islam, terj. Agus Mijanto dan Rozi Diyanti,(Depok: Ciber PKTTI-UI, 2000), 33. 
pewaris untuk melaksanakannya. Jika pewaris tidak melaksanakannya, wasiat tersebut dilaksanakan berdasarkan peraturan perundang-undangan. ${ }^{13}$

Persoalan wașiyyat al-wājibah di Syiria dan Jordan hanya berlaku bagi keturunan anak laki-laki dan seterusnya ke bawah dari jalur laki-laki saja, sedangkan cucu atau para cucu dari keturunan anak perempuan sekalipun dalam tingkat pertama yang menurut undang-undang wasiat Mesir menjadi penerima wasiyyat al-wājibah, tidak berhak menerimanya. Sementara itu di Tunisia dan Irak, wașiyyat al-wājibah hanya berlaku untuk cucu dari anak laki-laki maupun cucu dari anak perempuan dari generasi pertama saja, sedangkan untuk generasi seterusnya tidak berhak menerima wasilyyat al-wājibah. $^{14}$

Olehnya itu diketahui bahwa hukum keluarga dalam perkembangannya mendapat perhatian pemerintah dan ulama di dunia Islam, termasuk negara Kuwait yang terus menjadi pusat kajian hukum keluarga Islam, khususnya mazhab Maliki. ${ }^{15}$ Dalam hal ini persoalan yang akan dibahas dalan artikel ini adalah pembaruan hukum keluarga Islam dalam hal perwakafan dan wașiyyat al-wājibah.

\section{B. Negara Kuwait dalam Lintasan Sejarah}

Kuwait merupakan negara yang berbentuk emirat yang terletak di jazirah Arab kawasan Teluk. Negara ini berbatasan dengan Irak di sebelah utara, Teluk Persia di sebelah timur dan Saudi Arabia di sebelah selatan. ${ }^{16}$ Wilayahnya 170 km. memanjang dari utara ke selatan dan $90 \mathrm{~km}$ dari timur ke barat. ${ }^{17}$ Luas negara ini adalah 17.818 $\mathrm{km}^{2}$. Ibukota negara ini adalah Kuwait dengan mata uang Dinar. Bahasa resmi negara

\footnotetext{
${ }^{13}$ Abu Zahrah, Syarḥ Qānūn al-Wașiyyah (Al-Qāhirah: Dār al-Fikr al-'Arabī, 1978), 216.

${ }^{14}$ Sri Hidayati, "Ketentuan Wasiat Wājibah di Pelbagai Negara Muslim Kontemporer," Ahkam, Vol. XII No. 1 Januari 2012; 85, http//doi.org/10.15408/ajis.v12i1.982

${ }^{15}$ Tahir Mahmood, Family Law Reform in the Muslim Word (New Delhi: The Indian Law Institute, 1972), 4.

${ }^{16}$ Adolf Grohmann, "Kuwait" dalam M. Th. Houtsma, et al., eds., E.J. Brill's First Encyclopaedia of Islam 1913-1936, vol. 4 (Leiden-New York: E.J. Brill, 1993), 1172.

${ }^{17}$ Ida Supriyatni, "Kuwait" dalam Ensiklopedi Nasional, jil. 9 (Cet. 1; Jakarta: PT. Cipta Adi Pustaka, 1990), 257.
} 
adalah bahasa Arab, di samping bahasa Inggris. Islam menjadi agama resmi negara dan dipeluk oleh seluruh penduduknya. ${ }^{18}$

Walaupun Kuwait adalah negara kecil namun negara ini kaya minyak. Di perut bumi negara daerah Ahmadi (nama kota dekat Irak) ini tersimpan 9 juta ton metrik minyak dengan produksi sebanyak 985 ribu barel per hari. Kuwait juga memiliki 864 $\mathrm{m}^{3}$ gas alam dan sedikit nitrogen dan sulfur. Selain itu, negara ini memiliki hasil perikanan. ${ }^{19}$ Islam datang ke negara ini sejak masa Khalifah Umar ibn Khattab (15-30 H.) Islam yang berkembang di negara ini mengikuti aliran Sunni yang bemazhab Maliki dan Hanbali serta minoritas Syi'ah. ${ }^{20}$ Data OPEC tahun 2018 menerankan Kuwait sangat kaya dengan cadangan minyak dan gas alam. Cadangan minyak yang sudah diketahui sebesar 96,8 miliar barel, merupakan 10\% cadangan minyak dunia dan nomor 6 di dunia. Cadangan gas alam sebesar 1,498 triliun meter kubik. Kuwait memiliki sumber air bersih di Al-Rawdatayn dan Al-Shiqāyā, namun tidak mencukupi kebutuhan air bersih nasional. Kebutuhan air bersih didapat melalui penyulingan air laut. $^{21}$

Sejarah Kuwait dimulai pada abad XIX setelah pertempuran dengan Kerajaan Usmaniyah (Ottoman Empire) yang ingin memperluas daerah jajahan. Dengan bantuan Inggris, pada tahun 1914, Kuwait bisa mempertahankan wilayahnya dan sejak saat itulah wilayah Kuwait menjadi wilayah kekuasaan Inggris sebagai negara protektorat. $^{22}$

Tahun 1961, Kuwait menjadi merdeka. Enam hari kemudian, Kuwait diklaim sebagai wilayah Irak. Atas bantuan Inggris, Irak akhirnya mundur. Sejak itu pula negara-negara tetangga dalam Liga Arab mengakui kemerdekaan Kuwait. Setelah itu,

\footnotetext{
${ }^{18}$ Musthofa, "Pembaharuan Hukum Islam di Kuwait: Studi Wasiat Wajibah," dalam H. M. Atho Muzdhar dan Khairuddin Nasution, eds, Hukum Keluarga di Dunia Islam Modern (Cet. 1; Jakarta: Ciputat Press, 2003), 165. Lihat pula John L. Esposito, ed., The Oxford Ensyclopedia of the Modern Islamic Word, terj. Eva Y. N., et al., Ensiklopedi Oxford dalam Dunia Islam Modern, jil.6 (Cet. 2; Bandung: Mizan, 2002), 5-6.

${ }^{19}$ Esposito, ed., the Modern World, 5.

${ }^{20}$ Mahmood, the Muslim World, 4.

${ }^{21}$ Kedutaan Besar Republik Indonesia, "Profil Negara Kuwait," https://kemlu.go.id/kuwaitcity /id/pages/profil_negara_kuwait/1585/etc-menu (diakses tanggal 21 Nopember 2019).

${ }^{22}$ Growmann, "Kuwait," 1172. Lihat pula Dewan Redaksi Ensiklopedi, Ensiklopedi Islam, jil. 3 (Cet. 4; Jakarta: Ichtiar Baru Van Hoeve, 1997), 87-88.
} 
hubungan Irak dan Kuwait menjadi pulih kembali. Namun pada tanggal 2 Agustus 1990, Irak sempat melancarkan agresi yang kedua ke Kuwait, dan harus mundur lagi atas desakan Amerika dan sekutunya enam bulan kemudian. ${ }^{23}$ Mestinya pada tahun kemerdekaan Kuwait, negara yang kaya minyak ini sudah mendaftarkan diri untuk menjadi anggota Perserikatan Bangsa-Bangsa (PBB). Namun karena Uni Soviet dan Irak menentang rencana itu, maka negara ini bisa resmin menjadi anggota PBB baru dua tahun kemudian. ${ }^{24}$

Pada saat menjadi wilayah Inggris, Kuwait harus menerima sistem hukum dan administrasi Barat, maka dengan beberapa perubahan, Hukum Inggris (British-Indian Law), termasuk Indian Penal Law 1980 diterapkan bagi penduduk non Arab di negara ini, sedangkan untuk penduduk Islam masih diberlakukan hukum Islam, khususnya bidang hukum keluarga. Sistem hukum di negara ini pada saat ini merupakan perpaduan British common law, French civil law, Egyptian civil law dan hukum Islam (Syariah). Parlemen Kuwait disebut dengan National Assembly (Majlis al-Ummah). Anggota National Assembly terdiri atas 75 orang, di mana 50 orang yang dipilih lewat suara rahasia dan 25 orang yang diangkat oleh Amir. Masa kerja National Assembly adalah 4 tahun; pemilihan National Assembly terakhir adalah 26 November 2016. Tugas Parlemen adalah membuat UU dan mengawasi kabinet pemerintahan. Parlemen memiliki hak bertanya dan interpelasi serta mengajukan mosi tidak percaya terhadap Menteri. $^{25}$

\section{Perkembangan Hukum Keluarga Islam di Kuwait}

Perkembangan hukum di Kuwait mengalami perkembangan yang signifikan (produk hukum tahun 1951-1961). Pada masa kekuasaan Amir Syaikh Abdullah alSalim al-Sabah banyak disusun hukum baru, di antaranya: 1) Hukum Syariah tentang waqf 1951 yang menjadikan wakaf keluarga menjadi dilarang pada keadaan tertentu (terniable in certain spesified circumtances); 2) Civil and Commercial Prosedure Code

\footnotetext{
${ }^{23}$ Center for Research and Studies on Kuwait, The Aggression on Kuwait: the Truth and the Tragedy (t.tp: 1916 H./1996 M.), 55.

${ }^{24}$ Don Peretz, The Middle East Today, ed. 4 (New York: Prager, 1986), 489.

${ }^{25}$ Kedutaan Besar Republik Indonesia, "Profil Negara Kuwait."
} 
1960; 3) Civil Code 1961; 4) Commercial Code 1961; 5) Criminal Procedure Code 1961; 6) Law on Damage $1961 .^{26}$

Undang-undang yang lahir sejak tahun 1960 adalah karena hasil bantuan ahli hukum Arab yang terkenal, yaitu 'Abd al-Razaq al-Sanhurì yang mulai berkarya di Kuwait sejak tahun 1959. Selanjutnya pada tahun 1959, Amir Kuwait mendapat fasilitas untuk membuat kodifikasi hukum, maka selama 2 tahun banyak tersusun hukum yang didasarkan pada materi Aglo-Egyptian dan French Legal. ${ }^{27}$

Status protektorat Kuwait terhadap Inggris yang berakhir sejak kemerdekaannya pada tanggal 19 Juni $1961,{ }^{28}$ maka pada tahun 1962 diundangkan Konstitusi (Undang-Undang Dasar/UUD) negara yang menjadikan syariat (Islam) sebagai dasar hukum di negara ini. ${ }^{29}$ UUD ini menyatakan Islam sebagai agama negara dan Syariah sebagai sumber hukum utama di negara ini. ${ }^{30}$ Lebih lanjut UUD ini menyatakan 'keluarga adalah dasar (pembentukan) masyarakat yang dibangun atas dasar agama, akhlak dan patriotisme. ${ }^{31}$ Oleh karena itu, hukum-hukum tentang hubungan dan hak milik keluarga harus diatur berdasarkan hukum syariat.

Pada tahun 1963, Komite Nasional Kuwait berdasarkan ketetapan UUD ini berhasil menyusun sejumlah hukum baru dan mengubah beberapa hukum yang berlaku di negara ini sebelum merdeka. Terlebih sejak tahun 1965, Pemerintah (Amir) memberi kesempatan kepada para ahli untuk mengadakan perubahan hukum dalam bidang yang lebih luas, ${ }^{32}$ di antaranya ketetapan tentang warisan (succession). ${ }^{33}$ Selain itu, Kuwait juga memiliki Inheritence Law Reform 1971 and Further Legislation (perbaikan/perubahan hukum kewarisan). ${ }^{34}$

\footnotetext{
${ }^{26}$ Tahir Mahmood, Personal Law in Islamic Countries (New Delhi: Academy of Law and Religion, 1987), h. 88.

${ }^{27}$ Musthofa, Wasiat Wajibah, 167.

${ }^{28}$ Grohmann, "Kuwait," 1172. Lihat pula Center for Research and Studies on Kuwait, The Aggression, the Tragedy, 92.

${ }^{29}$ Esposito, the Modern World, 5.

${ }^{30}$ Amin, Islamic Law and Its Implication for Modern World (Scotland, UK-Royston, 1989), 181.

${ }^{31}$ Mahmood, Personal, 88.

${ }^{32}$ Peretz, East Today, 489.

${ }^{33}$ Mahmood, Personal, 89.

${ }^{34}$ Muhammad Amin Suma, Hukum Keluarga Islam di Dunia Modern (Cet. 1; Jakarta: PT Raja Grafindo Persada, 2004), 153.
} 


\section{Bidang Perwakafan}

Wakaf (waqf $=$ menahan, mengekang, menghentikan). Dalam pengertian istilahnya, menghentikan perpindahan hak milik atas suatu harta yang bermanfaat dan tahan lama dengan cara menyerahkan harta kepada pengelola, baik perorangan, keluarga maupun lembaga untuk dipergunakan bagi kepentingan umum di jalan Allah swt. $^{35}$

Ada lima rukun dari wakaf, yaitu: Pertama: waqīf (orang yang berwakaf), dengan syarat: 1) pemilik sah dari harta yang diwakafkan, dengan bukti-bukti yang sah sesuai dengan ketentuan yang berlaku; 2) dewasa, menyadari dan mengetahui tujuan melepaskan hak miliknya kepada pihak lain; 3) tidak boleh mempunyai utang jika seluruh harta yang akan diwakafkan hanya cukup untuk membayar utangnya; Kedua: mauqūf (harta yang diwakafkan) tahan lama dan bermanfaat. Pada masa Rasulullah saw., benda yang diwakafkan itu biasa berupa tanah atau kebun. Namun para ulama kemudian membolehkan barang tak bergerak lain, seperti mobil dengan syarat tahan lama dan bermanfaat bagi kepentingan umum. Bahkan mazhab Maliki dan Syi'ah membolehkan wakaf benda-benda bergerak, baik yang selama-lamanya maupun untuk beberapa waktu yang ditentukan sesuai dengan akad wakaf yang dilakukan; Ketiga: mauqüf 'alaīh (tujuan wakaf), yaitu untuk kepentingan umum dalam upaya mencari keridhaan Allah swt.; Keempat: sifat wakaf, yaitu kata-kata atau pernyataan yang diucapkan orang yang berwakaf harus jelas dan lebih baik jika dilakukan secara tertulis serta ada saksi yang dianggap patut dalam akad wakaf itu; Kelima: penerima yang kemudian akan mengelola harta wakaf, baik perorangan maupun lembaga pengelola tanah wakaf, yang disebut nādzir yang mengucapkan qabūl (penerimaan). ${ }^{36}$

Dalam perjalanan sejarah Islam, ada dua jenis wakaf yang pernah berlaku dan dilakukan umat Islam. Pertama: waqf ahli, yaitu wakaf yang diberikan kepada perorangan. Adanya jenis wakaf ini menimbulkan kecenderungan untuk mementingkan diri sendiri, sehingga harta waqf ahli itu sering digunakan hanya untuk kepentingan pribadi. Misalnya diberikan kepada ahli warisnya yang tidak memperhatikan

\footnotetext{
${ }^{35}$ Dewan Redaksi Ensiklopedi, Ensiklopedi Islam, jil. 3, 168.

${ }^{36}$ Ibid.
} 
kepentingan umat. Oleh sebab itu, negara seperti Suriah dan Mesir yang semula membolehkan adanya praktek waqf ahli, sekarang tidak memberlakukannya lagi; Kedua: waqf khairi, yaitu wakaf yang sejak diikrarkannya memang diperuntukkan bagi kepentingan umum, misalnya untuk pembangunan masjid, sekolah dan sebagainya. Lembaga wakaf dalam bentuk inilah yang masih umum berjalan di negara-negara Islam. $^{37}$

Sebagaimana Hukum Wakaf Mesir 1946 dan Hukum Wakaf Keluarga Libanon 1947, maka Undang-undang Wakaf (1951) Kuwait banyak mendapat inspirasi dari produk hukum ke dua negara tersebut. ${ }^{38}$ Oleh sejak itu, pelaksanaan wakaf keluarga di Kuwait menjadi terbatas sesuai aturan tersebut.

\section{Bidang Wașiyyat Wäjibah}

Perundang-undangan yang sangat penting berhubungan dengan warisan adalah hukum wașiyyat wājibah (law on obligatory bequest atau qanūn waṣiyyah al-wäjibah) tahun 1971, yang diundangkan tanggap 4 April 1971. Perundang-undangan ini dapat memberikan manfaat bagi cucu yang orangtuanya meninggal (descendants of the predeceased children of deceased persons), bahwa menurut aturan ini cucu tersebut berhak mendapat bagian. Dalam hukum kewarisan, hukum ini dikenal sebagai waris pengganti. Pembaruan hukum sejenis ini telah terjadi sebelumnya di negara-negara Arab, seperti Mesir, Maroko, Syria dan Tunisia. Setelah Kuwait memberlakukan model hukum ini, maka Algeria, Irak dan Yordania juga berbuat serupa. ${ }^{39}$

Istilah wașiyyat wäjibah dipergunakan pertama kali di Mesir melalui Hukum Waris 1946 guna menegakkan keadilan dan membantu cucu yatim. ${ }^{40}$ Hukum Wasiyyat Wäjibah Kuwait 1971 dibuat secara sederhana yang hanya memuat empat pasal. Ketetapan ini bermanfaat bagi anak-anak dari anak laki-laki yang meninggal (ibn al$i b n)$ atau anak laki-laki dari anak laki-laki terus ke bawah, sedangkan untuk garis anak perempuan hanya berlaku untuk anak dari anak perempuan saja (tidak berlanjut sampai

\footnotetext{
${ }^{37} \mathrm{Ibid}$, jil. 5, 170.

${ }^{38}$ Mahmood, Personal, 88

${ }^{39}$ Musthofa, Wasiat Wajibah, 168.

${ }^{40}$ M. Atho Muzdhar, Membaca Gelombang Ijtihad: Antara Tradisi dan Liberasi (Cet. 1; Yogyakarta: Titian Ilahi Press,1988), 163-164.
} 
generasi selanjutnya). Pemberian wasiat ini harus tidak melebihi dari 1/3 (sepertiga) harta yang ditinggalkan si mati. ${ }^{41}$ Ketentuan ini meskipun menderivasi dari undangundang Mesir, hakekatnya berangkat dari penafsiran terhadap firman Allah dalam Q.S. al-Baqarah/2: 180 .

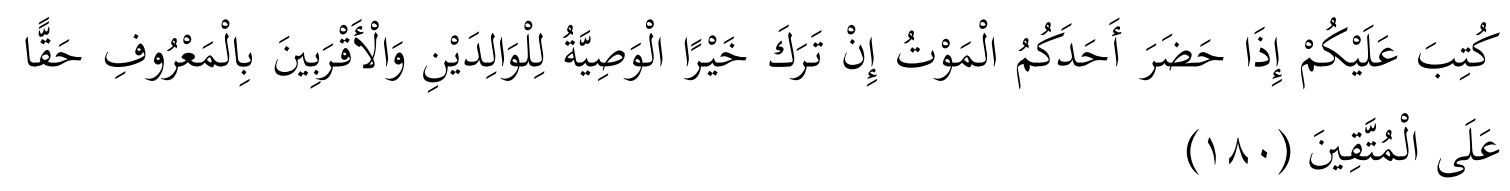

Terjemahnya:

Diwajibkan atas kamu, apabila maut hendak menjemput seseorang di antara kamu, jika dia meninggalkan harta, berwasiat untuk kedua orang tua dan karib kerabat dengan cara yang baik, (sebagai) kewajiban bagi orang-orang yang bertakwa. ${ }^{42}$

Menurut mufassir dan fuqahā tradisional terhadap ayat ini, wașiyyat hanya diberikan kepada orangtua dan kerabat dekat. Namun, sebagian besar ahli hukum Islam memandang ayat ini di-nasakh oleh Q.S. al-Nisā'/4: 7 dan hadis Nabi Muhammad saw. berikut ini:

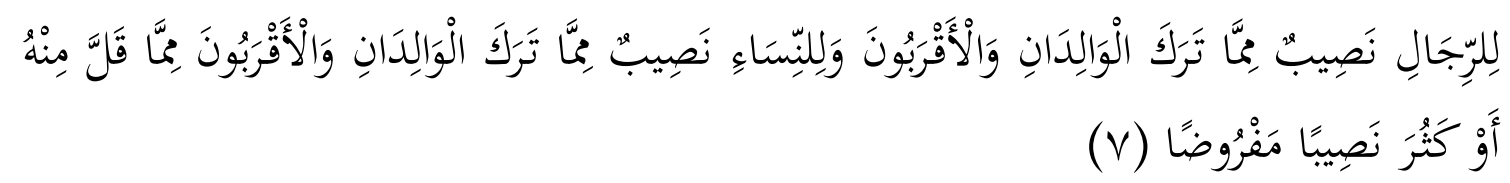

Terjemahnya:

Bagi orang laki-laki ada hak bagian dari harta peninggalan ibu-bapa dan kerabatnya, dan bagi orang wanita ada hak bagian (pula) dari harta peninggalan ibu-bapa dan kerabatnya, baik sedikit atau banyak menurut bahagian yang telah ditetapkan. ${ }^{43}$

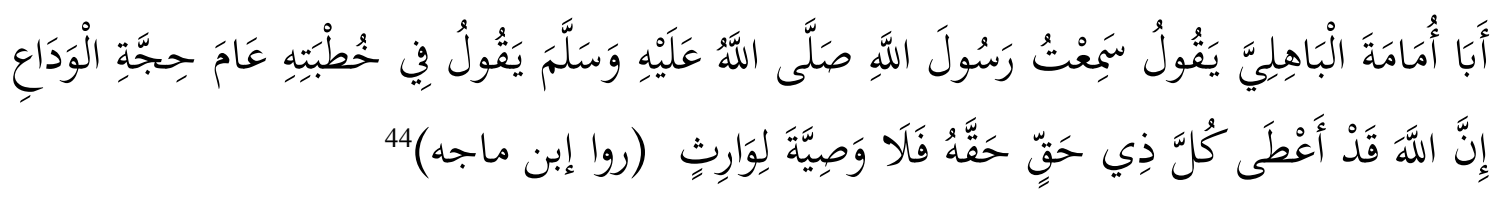

\footnotetext{
${ }^{41}$ Mahmood, Personal, 89.

${ }^{42}$ Iwan Setiawan dan Agus Subagio, Al-Qur'anul Karim: Tahfiz Junior (Bandung: Cordoba, 2018), 27.

${ }^{43}$ Ibid., 78.

${ }^{44}$ Al-Ḥāfiz Abì Abdillah Muhammad bin Yazìd, Sunan Ibn Mājah, al-Kitāb al-Wașāyā, al-Bāb Lā Wașiyyah li al-Wäriṣ No. Hadis: 2704 dalam Mausū'ah al-Hadiṣ al-Syarif ver. 2 [CD ROM]. Jami ‘ al-Ḥuqūq Mahfūsah li Syirkah al-Barāmij al-Islāmiyah al-Daūliyah, 1991-1997.
} 
Artinya:

Abu Umāmah al-Bāhiliyyi berkata bahwasanya dia mendengar Rasulullah saw. berkata dalam khutbah hari Haji al-Wadā' bahwa sesungguhnya Allah swt. telah memberikan bagian kepada keturunan/karib kerabat sesuai haknya, olehnya itu tidak ada wasiat untuk para ahli waris.

Hadis ini walaupun hadis ahad yang me-mansukh-kan Alquran, namun hadis ini telah memiliki nilai mutawātir karena sangat berkembangnya dalam masyarakat dan diterima baik oleh para fuqahā' yang karenanya dapatlah dipergunakan untuk memansukh-kan Alquran. ${ }^{45}$ Juga karena kebutuhan maka hal ini dibenarkan atas ijma' ulama, sehingga ada yang mengatakan di-nasakh dengan ijma ${ }^{, 46}$ Akan tetapi sebagian ulama yang lain berpendapat bahwa ayat itu hanya me-nasakh sebagian saja, yaitu orang-orang yang bersangkutan dan keluarga dekat yang menjadi ahl al-fara'id (penerima bagian tertentu dalam warisan). ${ }^{47}$

Sebagaimana disebutkan sebelumnya bahwa penduduk Kuwait memeluk tiga mazhab, yaitu Maliki, Hanbali dan minoritas Syi'ah. Menurut Imam Malik, wașiyyat boleh dilaksanakan bila disetujui oleh ahli waris. Bila yang menyetujui hanya sebagian, wașiyyat diambilkan dari orang yang membolehkan saja. ${ }^{48}$ Sedang menurut Ibn Qudamah, pengikut mazhab Hanbali, wasiyyat kepada ahli waris apabila dikehendaki boleh. ${ }^{49}$ Sedangkan Syi'ah Imamiyah berpendapat, wașiyyat boleh untuk ahli waris maupun bukan ahli waris dan tidak bergantung pada persetujuan ahli waris lainnya sepanjang tidak melebihi $1 / 3$ harta warisan. ${ }^{50}$

\footnotetext{
${ }^{45}$ Tengku Muhammad Hasbi ash-Shiddieqy, Fiqh Mawaris, ed. 2 (Cet. 1: Semarang: PT. Pustaka Rizki Putra, 1997), 301.

${ }^{46}$ Al-Zarqanī, Syarh al-Zarqanī 'ala Muwatta' al-Imām Malik, juz 4 (Beirut: Dār al-Kutub al'Ilmiyyah, 1990), 86.

${ }^{47}$ Abdul Azis Mohammed Zaid, The Islamic Law of Bequest (London: Scorpion Publishing Ltd., 1986), 11.

${ }^{48}$ Al-Zarqanì, al-Imām Malik, juz 4, 86.

${ }^{49}$ Abdillah ibn Qudamah al-Maqdisi, Al-Kāfí fĭ Fiqh al-Imām al-Muhajjal Aḥmad ibn Hanbal, juz 2 (Beirut: al-Maktab al-Islami, 1988), 479.

${ }^{50}$ Mahkamah Mesir dahulu menggunakan mazhab empat, lalu diganti menggunakan mazhab Imamiyah. Lihat Muhammad Jawwad al-Muginiyyah, Al-Fiqh 'ala al-Mazāhib al-Khamzah, terj. Afif Muhammad, Fiqh Lima Mazhab, jil. 2 (Jakarta: Basrie Press, 1994), 240.
} 
Pendapat yang lebih tegas berasal dari kalangan mazhab Zahiri, Ibn Hazm menyatakan, wajib bagi setiap muslim ber-wasiyyat kepada keluarga dekat yang tidak mendapatkan warisan, baik karena warisannya diambil oleh ahli waris yang lebih berhak maupun karena sebenarnya tidak mendapat warisan. Pandangan ini berdasar Q.S. al-Baqarah/2: $180^{51}$ dan didukung fakta Alquran tetap mengakui adanya wasiyyat bila pembagian warisan masih tersisa (setelah pembayaran wasiyyat dan hutang). ${ }^{52}$ Olehnya itu, wașiyyat untuk keluarga dekat masih dibolehkan. Ahli hukum Islam mendukung pendapat ini dengan berdasar hadis:

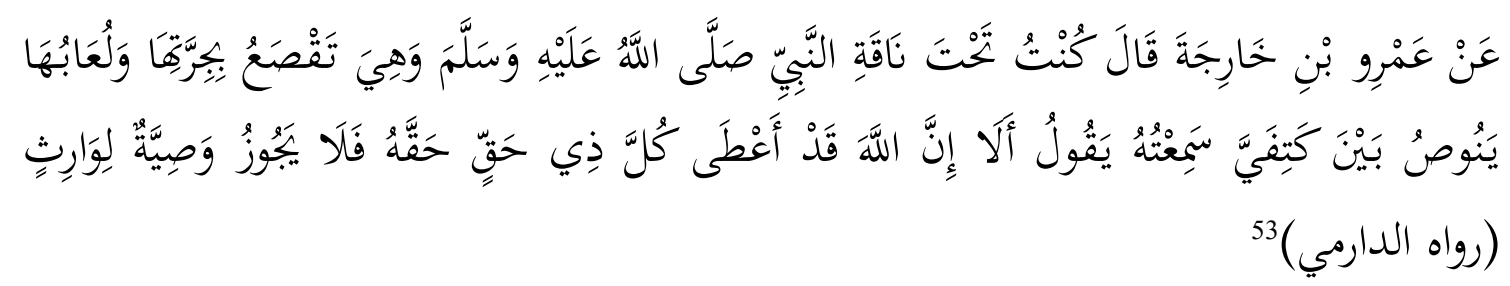

Artinya:

Dari Amri bin Khārijah berkata bahwa saya berada di bawah onta Nabi saw. dan onta tersebut terjatuh sambil terseret dan air liurnya tertinggal di antara bahu dan lehernya, dan saya mendengar beliau bersabda: ketahuilah sesungguhnya Allah swt. telah memberikan bagian kepada keturunan/karib kerabat sesuai haknya, olehnya itu tidak boleh wasiat untuk para ahli waris.

Sedangkan al-Mawardi, pengikut mazhab Syafi'i berpendapat, wasiyyat kepada kerabat dekat adalah sunnah bukan wajib. ${ }^{54}$ Selain itu perlu dikemukakan pula defenisi keluarga dekat yang secara eksplisit telah dinyatakan Rasulullah saw. dalam salah satu sabdanya, yaitu:

\footnotetext{
${ }^{51}$ Meskipun ayat ini dianggap mansukh, namun mazhab Zahiri berpendapat bahwa yang dikecualikan hanya kerabat yang menerima warisan, sehingga orang yang tidak menerima warisan wajib diberi wasiyyat. Lihat Ibn Hazm, Al-Muhalla dalam Ahmad Muhammad Syakir, juz 9 (t.t: Dār al-Fikr, t.th.), 314 .

${ }^{52}$ Lihat Q.S. al-Nisā'/4: 11-12 dan al-Baqarah/2: 240.

${ }^{53 ،}$ 'Abdullah ibn 'Abd al-Rahmān al-Dārimī, Sunan al-Dārimīi, al-Kitāb al-Wașāyā, al-Bāb Lā Wașiyyah li al-Wāriș, No. Hadis: 3128 dalam Mausū'ah al-Hadịs al-Syarïf ver. 2 [CD ROM]. Jamī' alḤuqūq Mahfūsah li Syirkah al-Barāmij al-Islāmiyah al-Daūliyah, 1991-1997.

${ }^{54}$ Habib al-Mawardi, Al-Hawi al-Kabir dalam Mahmud Satraji (ed.), Juz 10 (Bairut: Dār al-Fikr, 1994), 149.
} 


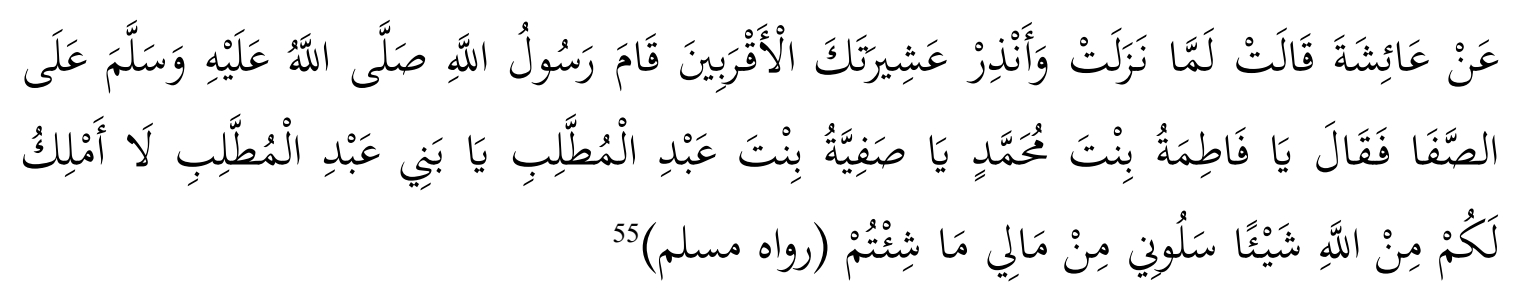

Artinya:

Dari 'Āisyah berkata takkala turun ayat Wa Anzir 'Asyirataka al-Akrabïn(Q.S. alSyu'arā'/26: 214) berdirilah Rasulullah saw. di barisan (saf), lalu bersabda: Wahai Fatimah binti Muhammad, wahai Șafiyyah binti 'Abd al-Muttalib, tiadalah saya memiliki sesuatu untuk kalian dari Allah kehilanganku dari hartaku apa-apa yang kalian inginkan (H.R. Muslim).

Kaitannya dengan ini Rasulullah saw. menunjuk putrinya Fatimah termasuk keluarga dekatnya. Ulama Malikiyah menyatakan bahwa kerabat dari ayah yang tidak menerima warisan dapat menerima wasiyyat. Sedangkan kerabat dari garis ibu meskipun tidak menerima warisan tidak juga berhak menerima wasiyyat. ${ }^{56}$ Kalangan Hanabilah menyatakan, wașiyyat diberikan kepada keluarga yang paling dekat. Oleh karena itu, ayah atau anak hendaknya lebih didahulukan mendapat wasiyyat. $^{57}$ Menurut Ibn Hazm, kerabat adalah orang-orang yang ada hubungannya dengan mayit dari garis ayah dan ibu. ${ }^{58}$ Menurut Imam Malik sebagaimana dikutip al-Mawardi, keluarga dekat itu semua orang yang bisa mewarisi bukan orang dari kelompok zaw alarhām yang tidak bisa mewarisi. ${ }^{59}$ Di sisi lain, Nabi saw. menyuruh memberikan wajiyyat kepada keluarga dekat. Sebagaimana sabdanya:

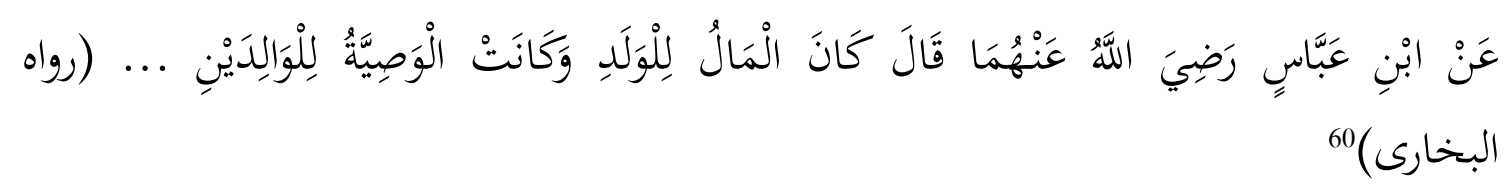

${ }^{55}$ Imām Muslim ibn al-Hajāj al-Qusyairī al-Naisaburī, Șahị Muslim, al-Kitāb al-Imān, al-Bāb Fì Qaulihi Ta'āla Wa Anzir 'Asyìrataka al-Akrabīn, No. Hadis: 304 dalam Mausū'ah al-Hadịs al-Syarîf ver. 2 [CD ROM]. Jamī‘ al-Ḥuqūq Mahfūsah li Syirkah al-Barāmij al-Islāmiyah al-Daūliyah, 1991-1997.

${ }^{56}$ Abd al-Raḥmān al-Jazirì, Kitāb al-Fiqh 'alā al-Mazāhib al-'Arba'ah, juz 3 (Bairut: Dār alKutub al-'Ilmiyyah, 1990), 300.

${ }^{57}$ Ibid., 304.

${ }^{58}$ Ibn Hazm, al-Muhalla, 314.

${ }^{59}$ Al-Mawardi, Al-Hawi al-Kabīi, 149.

${ }^{60} \mathrm{Abi}$ Abdillah Muhammad bin Ismaì bin Ibrāhim bin al-Mugīrah bin Barzbah al-Bukharī, Sahịḥ al-Bukharī, al-Kitāb al-Wașāyā, al-Bāb Lā Wașiyyah Liwāris, No. Hadis: 2542 dalam Mausū'ah al-Hadị̣ al-Syariff ver. 2 [CD ROM]. Jamī‘ al-Ḥuqūq Mahfüsah li Syirkah al-Barāmij al-Islāmiyah alDaūliyah, 1991-1997. 
Artinya:

Dari Ibn 'Abbās ra. berkata adalah harta untuk anak dan wasiat untuk ibu bapak.... (H.R. al-Bukhāri)

Para ahli hukum Islam Mesir kontemporer memaksudkan 'keluarga dekat' dengan cucu yang orangtuanya telah meninggal terlebih dahulu sebelum kakek atau neneknya (cucu yatim), ${ }^{61}$ maka cucu yatim diberi dengan pemberian wașiyyat. ${ }^{62}$ Dasar pandangan ini adalah karena cucu yatim pada hakekatnya adalah kerabat yang menjadi tanggungjawab pewaris (ayah/ibu yang meninggal). ${ }^{63}$ Hal ini sesuai dengan nilai ideal Islam bahwa prinsip waris hanya diperuntukkan bagi keluarga dekat yang derajatnya paling dekat dengan pewaris. Jadi pemberian wașiyyat kepada cucu yatim sesuai dengan prinsip ideal Islam itu.

Untuk lebih jelasnya berikut ini dikutipkan butir-butir tentang Wașiyyat Wajibah pada Undang-Undang Nomor 5 Tahun 1977, yaitu:

1. Bila seorang yang meninggal (kakek/nenek) tidak berwasiyat kepada cucu dari anak-anaknya yang meninggal sebelumnya atau meninggal bersamaan dengan kakek, bagian (warisan) ayah dari harta yang ditinggalkan kakek saat meninggal akan berpindah kepada anaknya (cucu) sebagai harta wasiyat yang harus diberikan kepadanya tapi tidak boleh melebihi sepertiga jumlah harta yang boleh diwasiyatkan. Cucu tersebut tidak termasuk ahli waris kakek yang meninggal yang tidak termasuk ahli waris kakek yang meninggal yang tidak memberinya dengan cara lain. Tanpa pertimbangan lain, itulah hak yang harus diberikan kepadanya.

Wasiat itu menjadi hak keturunan generasi pertama dari anak perempuan dari orang yang meninggal. Akan tetapi wasiat itu menjadi hak bagi garis keturunan laki-laki ke bawah yang akan menghalangi keturunannya sendiri, tapi bukan keturunan garis lain (garis perempuan, pen).

Bagian anak lelaki dari orang yang meninggalkan dibagi diantara anak-anak (cucu)-nya ke bawah sesuai prinsip kewarisan yang seakan-akan hubungan itu melalui orang yang dihubungkan kepada orang yang meninggal setelah dia dan

\footnotetext{
${ }^{61}$ N. J. Coulson, Succession in the Muslim Family (Cambridge: Cambridge University Press, 1971), 144-145. Lihat pula 'Abd al-Majid 'Abd al-Ḥamid al-Zibanī, Aḥkam al-Mawāris wa al-Ṭarikat wa al-Wasiyyat fỉ al-Syarì 'at al-Islamiyyah (t.t.: Dār al-Jamahiriyyah, 1993), 310-311.

${ }^{62}$ Muhammad Mustafa Khan, Islamic Law of Inheritance (New Delhi: Kitab Bhavan, 1989), 212.

${ }^{63}$ Coulson, the Muslim Family, 144.
} 
kematiannya terjadi pada saat generasi itu masih memiliki hubungan dengannya.

2. Jika orang yang meninggal berwasiat kepada cucu yang melebihi harta yang harus diwasiyatkan, pengaruhnya dianggap sebagai wasiyat biasa (optional). Dan jika dia berwasiat kurang dari batsa itu, kewajiban memenuhi wasiyat itu sebatas memenuhi haknya.

Jika wasiyat itu (mestinya) diberikan kepada beberapa orang akan tetapi si mati hanya berwasiyat untuk beberapa orang diantaranya, tidak kepada yang lainnya, maka wasiyat itu harus juga diberikan kepada mereka (yang tidak diberi wasiyat) sesuai haknya. Orang-orang yang tidak diberi wasiyat wajibah dan juga orang-orang yang diberi wasiyat kurang dari jumlah itu akan mengambil haknya dari sisa sepertiga harta yang boleh diwasiyatkan. Jika sisa harta itu tidak cukup, maka wasiyat yang diberikan itu menjadi bersifat optional.

3. (1) Wasiat wajibah lebih diutamakan daripada wasiat biasa (optional).

(2) Jika si mati tidak berwasiyat kepada cucu-cucu yang seharusnya mendapat wasiyat wajibah, tapi justru berwasiyat kepada yang lainnya, maka cucu-cucu itu akan mengambil haknya dari sisa sepertiga harta yang diwasiyatkan (jika masih ada sisa), atau mengambil harta yang diwasiyatkan kepada orang lain itu. $^{64}$

Dalam perkembangan pembaruan hukum di Kuwait sempat terhenti pada tahun 1976 ketika terjadi ketegangan di Parlemen yang menghendaki agar kepala negara (amir) mengundurkan diri). ${ }^{65}$ Akhirnya sekitar bulan Pebruari 1978, kepala negara membuat deklarasi bahwa sistem hukum Kuwait secara berangsur-angsur akan disesuaikan dengan syariat. Sebagai hasilnya tiga tahun kemudian sejumlah hukum baru dapat diselesaikan, di antaranya Undang-undang Hukum Keluarga (Code on Personal Law atau Qanun Ahwal al-Syakhșiyyah). Hukum ini didasarkan pada doktrin yang dipilih dari prinsip hukum Islam dan ketetapan hukum serupa dari Mesir dan Maroko. ${ }^{66}$

Selanjutnya pada periode tersebut juga telah disiapkan Ensiklopedi Hukum Islam yang diharapkan menjadi karya monumental di dunia Islam. ${ }^{67}$ Pada tahun 1980 juga telah diundangkan Civil Code. ${ }^{68}$

\footnotetext{
${ }^{64}$ Musthofa, Wasiat Wajibah, 172-173.

${ }^{65}$ Esposito, the Modern World, 6.

${ }^{66}$ Musthofa, Wasiat Wajibah, 173.

${ }^{67}$ Mahmood, Personal, 90.

${ }^{68}$ Amin, Modern World, 240.
} 
Berdasarkan penjelasan di atas terlihat bahwa pembaruan hukum keluarga di Kuwait dapat dikatakan terlambat bila dibandingkan dengan negara-negara lain. Hal ini kemungkinan diakibatkan oleh kemerdekaan yang dicapainya juga terlambat sehingga hukum itu baru mengalami pembaruan sejak tahun 1971 dengan diundangkannya hukum tentang Wasilyyat al-Wäjibah.

Berkenaan dengan hukum keluarga yang lain, seperti aturan pernikahan dan perceraian di negara Kuwait tidak disinggung karena penulis berasumsi bahwa persoalan tersebut masuk dalam kategori privat (pribadi), sehingga negara tidak terlalu turut campur dalam kedua persoalan tersebut. Hukum Islam yang dianut mereka sudah menjadi living law dalam kehidupan sehari-hari, apalagi hukum Islam telah menjadi agama resmi negara Kuwait. Hal ini juga dapat dipahami bahwa kedua persoalan tersebut dapat dilihat aturannya dengan melihat mazhab yang dianut penduduknya, yaitu mazhab Maliki, Hanbali dan minoritas Syiah.

Adapun persoalan wakaf dan wașiyyat wäjibah karena berhubungan dengan harta, maka pemerintah turut campur dalam urusan tersebut. Banyaknya praktek perwakafan di Kuwait dapat dipahami dari melihat realitas bahwa negara Kuwait kaya dengan sumber daya alamnya, kehidupan masyarakatnya sejahtera, sehingga mewakafkan sebagian harta mereka menjadi sebuah budaya bagi masyarakat Kuwait. Oleh sebab itu, dengan banyaknya praktek-praktek perwakafan ini, maka pemerintah sebagai pemegang kekuasaan tertinggi membuat sebuah aturan perundang-undangan, sehingga harta yang telah diwakafkan dapat diinventarisasi demi kepentingan masyarakat banyak. Begitu pula aturan wașiyyat wäjibah diatur agar nantinya si pewaris tidak meninggalkan anak-anaknya (ahli warisnya) dalam keadaan terluntalunta akibat pemberian wașiyyat yang berlebihan kepada seseorang.

\section{Kesimpulan}

Negara Kuwait adalah negara berbentuk emirat yang terletak di jazirah Arab kawasan Teluk, yang merdeka pada tahun 1961 dan merupakan wilayah kekuasaan Inggris sebagai negara protektorat. Perkembangan pembaharuan hukum keluarga di Kuwait dapat dilihat bahwa pada saat menjadi wilayah Inggris, Kuwait harus 
menerima sistem hukum dan administrasi Barat dengan beberapa perubahan, yaitu Hukum Inggris (British-Indian Law), termasuk Indian Penal Law 1980 diterapkan bagi penduduk non Arab di negara ini, sedangkan untuk penduduk Islam masih diberlakukan hukum Islam, khususnya bidang hukum keluarga.

Produk hukum yang dihasilkan pada tahun 1951-1961, di antaranya (a) Hukum Syariah tentang waqf 1951 yang menjadikan wakaf keluarga menjadi dilarang pada keadaan tertentu (terniable in certain spesified circumtances); yang terinspirasi dari Hukum Wakaf Mesir 1946 dan Hukum Wakaf Keluarga Libanon 1947; (b) Civil and Commercial Prosedure Code 1960; (c) Civil Code 1961; (d) Commercial Code 1961; (e) Criminal Procedure Code 1961; (f) Law on Damage 1961; Pada tahun 1962 diundangkan Konstitusi/UUD negara yang menjadikan Syariat sebagai dasar hukum utama negara Kuwait; Pada tahun 1978 terdapat Hukum Keluarga (Code on Personal Law atau Qanun Ahwal al-Syakhsiyyah) yang didasarkan pada doktrin yang dipilih dari prinsip hukum Islam dan ketetapan hukum serupa dari negara Mesir dan Nngara Maroko.

Hukum keluarga Kuwait yang berkenaan dengan kewarisan diatur dalam Undang-Undang Nomor 5 Tahun 1977 tentang Wașiyyat al-Wäjibah. Perundangundangan ini dapat memberikan manfaat bagi cucu yang orangtuanya meninggal bahwa menurut aturan ini cucu tersebut berhak mendapat bagian yang tidak lebih dari sepertiga harta dari si pewaris. Dalam hukum kewarisan, hukum ini dikenal sebagai ahli waris pengganti.

\section{Daftar Pustaka}

Amin, Islamic Law and Its Implication for Modern World. Scotland, UK-Royston, 1989.

Anderson, J. N. D. Islamic Law in the Modern World. Terj. Machnun Husain, Hukum Islam di Dunia Islam. Yogyakarta: Tiara Wacana, 1994.

Al-Bukhari, Abi Abdillah Muhammad bin Ismaì bin Ibrāhim bin al-Mugirah bin Barzbah. Sahịh al-Bukhari, al-Kitāb al-Wașāyā, al-Bāb Là Wașiyyah Liwāris, No. Hadis: 2542 dalam Mausū'ah al-Hadị al-Syarif ver. 2 [CD ROM]. Jami ‘ al-Ḥuqūq Mahfūsah li Syirkah al-Barāmij al-Islāmiyah al-Daūliyah, 1991-1997. 
Center for Research and Studies on Kuwait. The Aggression on Kuwait: the Truth and the Tragedy. T.tp: 1916 H./1996 M..

Coulson, N. J. Succession in the Muslim Family. Cambridge: Cambridge University Press, 1971.

Al-Dārimī, 'Abdullah ibn 'Abd al-Raḥmān. Sunan al-Dārimī, al-Kitāb al-Wașāāa, alBāb Là Wașiyyah li al-Wāriṣ, No. Hadis: 3128 dalam Mausū'ah al-Hadị alSyariff ver. 2 [CD ROM]. Jami'‘ al-Ḥuqūq Mahfüsah li Syirkah al-Barāmij alIslāmiyah al-Daūliyah, 1991-1997.

Dewan Redaksi Ensiklopedi. Ensiklopedi Islam. Jil. 3. Cet. 4; Jakarta: Ichtiar Baru Van Hoeve, 1997.

Esposito, John L., ed.. The Oxford Ensyclopedia of the Modern Islamic Word. Terj. Eva Y. N., et al., Ensiklopedi Oxford dalam Dunia Islam Modern. Jil.6.Cet. 2; Bandung: Mizan, 2002.

Grohmann, Adolf. "Kuwait" dalam M. Th. Houtsma, et al., eds., E.J. Brill's First Encyclopaedia of Islam 1913-1936. Vol. 4. Leiden-New York: E.J. Brill, 1993.

Ibn Hazm. Al-Muhalla dalam Ahmad Muhammad Syakir, Juz 9. T.t: Dār al-Fikr, t.th.

Ibn Yazīd, Al-Hạäiz Abì Abdillah Muhammad. Sunan Ibn Mājah, al-Kitāb al-Wasāyā, al-Bāb Lā Wașiyyah li al-Wāriṣ No. Hadis: 2704 dalam Mausūah al-Hadịs alSyarif ver. 2 [CD ROM]. Jamī' al-Ḥuqūq Mahfüsah li Syirkah al-Barāmij alIslāmiyah al-Daūliyah, 1991-1997.

Al-Jauziyah, Ibnu Qayyum. I'lam al-Muwaffiqīn al-Rab al-'Alamīn. Juz 3. Beirut: Dār al-Fikr, t.th.

Al-Jazirī, Abd al-Raḥmān. Kitāb al-Fiqh 'alā al-Mazāhib al-'Arba'ah. Juz 3. Bairut: Dār al-Kutub al-'Ilmiyyah, 1990.

Ka'bah, Rifyal. "Beberapa Permasalahan dalam Al-Ahwal Asy-Syakhsyiah (Hukum Keluarga) Mesir. Makalah. Jakarta: Departemen Agama RI., 19 September 2002.

Khallaf, Abdul Wahhab. Ilmu Ușul al-Fiqh. Bairut: Dār al-Fikr, t.th..

Khan, Muhammad Mustafa. Islamic Law of Inheritance.New Delhi: Kitab Bhavan, 1989.

Mahmood, Tahir. Family Law Reform in the Muslim Word. New Delhi: The Indian Law Institute, 1972.

Mahmood, Tahir. Personal Law in Islamic Countries. New Delhi: Academy of Law and Religion, 1987.

Al-Maqdisi, Abdillah ibn Qudamah. Al-Kăfí fì Fiqh al-Imām al-Muhajjal Aḥmad ibn Hanbal. Juz 2. Beirut: al-Maktab al-Islami, 1988.

Al-Mawardi, Habib Al-Hawi al-Kabïr dalam Mahmud Satraji. Juz 10. Bairut: Dār alFikr, 1994. 
Al-Muginiyyah, Muhammad Jawwad. Al-Fiqh 'ala al-Mazāhib al-Khamzah. Terj. Afif Muhammad, Fiqh Lima Mazhab. Jil. 2. Jakarta: Basrie Press, 1994.

Al-Munawir, Ahmad Warson. Al-Munawwir Kamus Arab - Indonesia. Yogyakarta: Pondok Pesantren al-Munawwir, t.th..

Musthofa. "Pembaharuan Hukum Islam di Kuwait: Studi Wasiat Wajibah," dalam H. M. Atho Muzdhar dan Khairuddin Nasution, eds, Hukum Keluarga di Dunia Islam Modern. Cet. 1; Jakarta: Ciputat Press, 2003

Muzdhar, M. Atho. Membaca Gelombang Ijtihad: Antara Tradisi dan Liberasi. Cet. 1; Yogyakarta: Titian Ilahi Press, 1988.

Al-Naisaburī, Imām Muslim ibn al-Hajāj al-Qusyairì. Șaḥ̣h Muslim, al-Kitāb al-Imān, al-Bāb Fì Qaulihi Ta'āla Wa Anzir 'Asyirataka al-Akrabìn, No. Hadis: 304 dalam Mausū'ah al-Hadị al-Syariff ver. 2 [CD ROM]. Jami' al-Huqūq Mahfüsah li Syirkah al-Barāmij al-Islāmiyah al-Daūliyah, 1991-1997.

Peretz, Don. The Middle East Today. Ed. 4. New York: Prager, 1986.

Qal'ahji, Muhammad Rawas, et al. Mu'jam Lugah al-Fuqahà' 'Arabi - Inklizi Afransi. Bairut: Lubnan, 1416 H/1996 M.

Setiawan Iwan, dan Agus Subagio. Al-Qur'anul Karim: Tahfiz Junior. Bandung: Cordoba, 2018.

Ash-Shiddieqy, Tengku Muhammad Hasbi. Fiqh Mawaris. Ed. 2.Cet. 1: Semarang: PT. Pustaka Rizki Putra, 1997.

Suma, Muhammad Amin. Hukum Keluarga Islam di Dunia Modern. Cet. 1; Jakarta: PT Raja Grafindo Persada, 2004.

Supriyatni, Ida. "Kuwait" dalam Ensiklopedi Nasional. Jil. 9. Cet. 1; Jakarta: PT. Cipta Adi Pustaka, 1990.

Zaid, Abdul Azis Mohammed. The Islamic Law of Bequest. London: Scorpion Publishing Ltd., 1986.

Al-Zarqani., Syarh al-Zarqanī 'ala Muwatța' al-Imām Malik. Juz 4. Beirut: Dār alKutub al-'Ilmiyyah, 1990.

Al-Zibanī, 'Abd al-Majid 'Abd al-Ḥamid. Aḥkam al-Mawāris wa al-Ṭarikat wa alWașiyyat fī al-Syarī at al-Islamiyyah. T.t.: Dār al-Jamahiriyyah, 1993. 